\title{
EPIPHYTIC BACTERIA BACILLUS SUBTILIS UZNU-18 FROM JERUSALEM ARTICHOKE (HELIANTHUS TUBEROSUS L.) - THE ACTIVE BIOCONTROL AGENT OF PHYTOPATHOGENIC MICROORGANISMS
}

\author{
Kakhramon Davranov ${ }^{1}$, Vyacheslav Shurigin ${ }^{1^{*}}$, \\ Absakhat Mammadiev', Kholida Ruzimova ${ }^{1}$ \\ ${ }^{\prime}$ National University of Uzbekistan, Almazar district, \\ 4 University str., Tashkent, 100174, Uzbekistan \\ ${ }^{2}$ Termez State University, 43 Khojaev str., \\ Termez, Surxondaryo, 732011, Uzbekistan, \\ e-mail: slaventus87@inbox.ru
}

We isolated a new strain of bacteria belonging to the genus Bacillus from the green leaves of Jerusalem artichoke also known as topinambour (Helianthus tuberosus L.) The aim of this work was to study physiological and biochemical features of the epiphytic strain Bacillus subtilis UzNU-18, its antagonistic activity, and conditions of formation of antimicrobial metabolites synthesized by this strain. Methods. Standard microbiological, molecular biological, biochemical, chromatographical and statistical methods was used. Results. The isolate UzNU-18 was isolated from the surface of green leaves of Jerusalem artichoke also known as topinambour (Helianthus tuberosus L). Upon screening, this isolate was selected as the best growth inhibitor of the tested phytopathogenic fungi species (Fusarium oxysporum, Fusarium culmorum, Fusarium solani, Rhizoctonia solani, Phytophtora capsici, Alteranria alternata) and bacteria species (Pseudomonas syringae, Erwinia carotovora, Xanthomonas beticola). The $16 \mathrm{~S} r R N A$ sequence analysis showed that the isolate (GenBank accession \# MH312004) belongs to Bacillus subtilis. Chromatography mass spectrometry analysis showed that Bacillus subtilis UzNU-18 produces antagonistic substance - 2.4-dimethylpentanone-3. Conclusions. Inoculation of soil with Bacillus subtilis UzNU-18 culture liquid reduced the infectious content in soil and contributed to better growth of wheat seedlings.

Keywords: epiphytic, Bacillus subtilis, phytopathogenic fungi, topinambour, antagonistic activity.

Among many factors that determine the productivity of a soil-plantmicroorganism system, microorganisms play a decisive role [1, 2]. Understanding this complex system is of a great practical importance for agriculture. Fundamental science today suggests rethinking of the perception of plants as autonomous organisms and considering their close functional integration with a variety of microsymbionts. The practical side of this issue is related to the urgent need to reduce the technogenic impact on the environment, to improve crop production by maximizing the biological potential of a plant itself and soil microbiota. The role of science in this process is to optimize the beneficial interaction of plants with microsymbionts. The annual damage caused to agriculture by phytopathogenic microorganisms only is 1.4 tri1lion US dollars, which is 5\% of total GDP and $20-25 \%$ of agricultural 
production [3]. Due to their ecological safety, selective action, relatively low cost bioformulations are becoming more popular as better measures against pathogens and insect pests of agricultural crops as compared to chemical ones. In addition, bioformulations have minimum impact on interrelation among the elements of the agroecosystem and does not lead to resistance in phytopathogenic microorganisms. Nevertheless, the insufficient effectiveness of many known microbiological plant protection products restricts their wide use as compared to agrochemicals. In this regard, it is important to find highly active, competitive, high antagonistic strains that can be used to develop biopesticides possessing broad spectrum of antimicrobial activity. The analysis of the literature data of recent years showed the efficacy of using Bacillus species in biological plant protection systems. Various commercial insecticide formulations based on Bacillus species have been developed and successfully applied [4-6]. Among those species are Bacillus subtilis [7], Bacillus thuringiensis [8, 9], Bacillus pumilus [10].

We isolated a new strain of bacteria belonging to the genus Bacillus from the green leaves of Jerusalem artichoke also known as topinambour (Helianthus tuberosus L.) The purpose of this work was to study physiological and biochemical features of the epiphytic strain Bacillus subtilis UzNU-18, its antagonistic activity, and conditions of formation of antimicrobial metabolites synthesized by this strain.

Materials and Methods. Isolation of epiphytic bacteria isolates. A total of 26 bacterial isolates were isolated from the surface of green leaves of topinambour (Helianthus tuberosus L.). To isolate the epiphytes TSA agar media was used 4-5 fresh leaves were put into $250 \mathrm{ml}$ flasks with $100 \mathrm{ml}$ of sterile tap water and mixed well for $2 \mathrm{~min}$. Then $250 \mu \mathrm{l}$ of suspension were transferred onto plates with TSA media and spread on the surface of agar with a sterile inoculation rod. The plates were incubated for 3 days at $27^{\circ} \mathrm{C}$. In 3 days newly emerging colonies were transferred to separate Petri dishes containing TSA media.

Determination of antagonistic activity of isolates. Phytopathogenic bacteria and fungi obtained from the Institute of Microbiology of the Academy of Sciences of the Republic of Uzbekistan were used for screening of isolated epiphytic bacteria for antagonistic activity against them. Phytopathogens were cultivated in beer mash (fungi) diluted with water up to seven times and meatpeptone broth (bacteria) in $250 \mathrm{ml}$ Erlenmeyer flasks on a microbiological shaker UWMT-12-250 (180 rpm) at $28-30^{\circ} \mathrm{C}$ for $2-3$ days. Antagonistic activity of the isolates was studied by the previously described method [11]. We made 3 holes in the agar on plates and placed suspensions of the isolates in nutrient media. Pieces of agar with growing bacteria or fungi were placed in the centre of the plate and incubated at $27^{\circ} \mathrm{C}$. The results were evaluated by measuring the diameter of growth inhibition zone.

Identification of the strain. To identify the strain, Bergey's manual of systematic bacteriology [12] as well as 16S rRNA analysis were used.

To carry out 16S rRNA analysis, DNA was isolated from the strain using bacterial colony growing on peptone agar media. The colony was transferred into Eppendorf tube with $20 \mu \mathrm{l}$ of sterile water, vortexed and incubated at $90^{\circ} \mathrm{C}$ for 20 minutes. The incubated suspension was centrifuged at $11000 \mathrm{rpm}$ 
for 8 minutes and supernatant was transferred to a new tube. Gel electrophoresis was conducted to check the DNA presence in supernatant. 16S rRNA was amplified with the polymerase chain reaction (PCR) using commercial primers (Sigma): 16SF 5'-GAGTTTGATCCTGGCTCAG-3 'and 16SR 5'-GAAAGGAGGTGATCCAGCC. The program of PCR was as follows: $94^{\circ} \mathrm{C}$ for $30 \mathrm{sec}, 30$ cycles $\left(94^{\circ} \mathrm{C}\right.$ for $20 \mathrm{sec}, 55^{\circ} \mathrm{C}$ for $35 \mathrm{sec}, 65^{\circ} \mathrm{C}$ for $80 \mathrm{sec}), 67^{\circ} \mathrm{C}$ for $25 \mathrm{~min}$. Gel electrophoresis of $16 \mathrm{~S}$ rRNA was conducted on $0.8 \%$ agarose gel. $16 \mathrm{~S}$ rRNA was used for sequencing using BigDye ${ }^{\mathrm{TM}}$ Terminator v 3.1 Cycle Sequencing Kit (Thermo Fisher Scientific) according to the protocol of manufacturer. Sequencing program cycle: $96^{\circ} \mathrm{C}$ for $5 \mathrm{~min}$, 30 cycles $\left(96^{\circ} \mathrm{C}\right.$ for $15 \mathrm{sec}, 55^{\circ} \mathrm{C}$ for $5 \mathrm{sec}, 65^{\circ} \mathrm{C}$ for $\left.4 \mathrm{~min}\right)$. Nucleotide sequences were analysed with the Sanger method [13]. The sequence identification was done using the Basic Local Alignment Search Tool (BLAST) and data of GenBank of the National Center for Biotechnology Information (NCBI) (http://www.ncbi.nlm.nih.gov/).

Determination of morphological-cultural and physiological-biochemical properties. The morphological-cultural and physiological-biochemical features of the isolated bacteria strains were studied according to generally accepted methods [14, 15].

Submerged cultivation of Bacillus subtilis UzNU-18 was carried out on a microbiological shaker UVMT-12-250 (Russia) in $250 \mathrm{ml}$ Erlenmeyer flasks containing $100 \mathrm{ml}$ media (molasses - $30 \mathrm{~g}$; extract from the cottonseed meal - $20 \mathrm{~g}$; corn extract - $5 \mathrm{~g} ; \mathrm{KH}_{2} \mathrm{PO}_{4}-10 \mathrm{~g} ; \mathrm{MgSO}_{4} \times 7 \mathrm{H}_{2} \mathrm{O}-0.05 \mathrm{~g}$; $\left.\mathrm{NH}_{4} \mathrm{NO}_{3}-1.5 \mathrm{~g} ;\left(\mathrm{NH}_{4}\right)_{2} \mathrm{MoO}_{4} \times 5 \mathrm{H}_{2} \mathrm{O}-0.01 \mathrm{~g} ; \mathrm{H}_{2} \mathrm{O}-1 \mathrm{~L}\right)$ with rotation speed $180 \mathrm{rpm}$ at $30-32^{\circ} \mathrm{C}$ for $3-4$ days.

The content of common sugars was determined after preliminary conducted inversion of media [16].

Cells titer of the bacteria were determined by plating on peptone agar (Koch method) [15].

Determination of antimicrobial substance. The first stage of isolation of Bacillus subtilis UzNU-18 antimicrobial metabolites was carried out from the dried supernatant of liquid culture, which was resuspended in solvents: acetone, ethanol and isopropanol at different $\mathrm{pH}$ conditions of culture liquid in 12 hours. Initially the volume of culture liquid was reduced by vacuum evaporation on a rotary evaporator.

The extraction was also carried out in a separator funnel with hydrophobic solvents: benzene, chloroform, hexane, butanol, diethyl ether. After extraction, the organic layer was separated on a funnel, dewatered with sodium sulphate, concentrated to a minimum volume and tested by the holes method on Petri dishes against fungi and bacteria. After the extracts were added to the holes, the Petri plates were left open until the solvent evaporated completely and incubated at $30^{\circ} \mathrm{C}$ for 24 hours, followed by measuring the diameter of inhibition zones.

The separation of the mixture of substances isolated from culture liquid was done by thin-layer chromatography using Silufol UV-254 TLC plates (Czech republic) in the experimentally selected system of N-butanol-acetic acid-water (4:1:1) with subsequent visualization in UV light. The amount of the sample applied to the plates was 20-25 $\mu 1$. Antibacterial activity of fractions against Pseudomonas syringae were detected by bioautography [17]. 
To identify metabolites with antibacterial activity synthesized and secreted by Bacillus subtilis UzNU-18, respective areas were cut from the chromatographic plates and eluted with methanol through the funnel with a porous glass filter. The absorption spectrum of the isolated substance was recorded with Shimadzu UV-1800 spectrophotometer (Japan). Separation and identification of substances were conducted by means of method of liquid chromatography with mass detection using LCMS-8040 Triple Quadrupole Liquid Chromatograph Mass Spectrometer (Shimadzu). Separation was con-

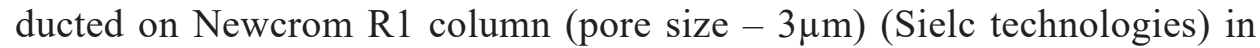
a $\mathrm{MeCN} / \mathrm{H}_{2} \mathrm{O} / \mathrm{CH}_{2} \mathrm{O}_{2}-30 / 70 / 0.1$ system at flow rate $1.0 \mathrm{ml} / \mathrm{min}$. Detection conducted at $280 \mathrm{~nm}$. Mass spectrum received at $70 \mathrm{EV}$, the temperature of the ionization chamber $-220^{\circ} \mathrm{C}$.

Evaluation of plant protection properties of Bacillus subtilis UzNU-18. Plant protection properties of Bacillus subtilis UzNU-18 were evaluated in the model experiments using growing wheat seedlings in sterile soil inoculated with the antagonist and commonly used in testing phytopathogenic microorganisms (Fusarium oxysporum or Pseudomonas syringae).

During model experiments Bacillus subtilis UzNU-18 culture liquid with initial titer of $6.5 \times 10^{8} \mathrm{CFU} / \mathrm{ml}$ was inoculated into soil. Liquid culture cultivated for 48 hours were centrifuged, washed, resuspended with sterile water to the initial volume and used to inoculate soil in the amount of $10 \%$ of its weight. Pre-sprouted wheat seeds were sowed into plastic pots with prepared soil and their development was observed during 4 weeks. The results of experiment were evaluated by the weight of control plants as compared to treated plants.

Statistical analysis. All experiments performed in 3 replicates. Experiments repeated twice and arranged in completely randomized block design with 6 replicates of each treatment. The data was subjected to analysis of variance (ANOVA) using Statistica 6.0 program.

Results. We isolated from the surface of topinambour leaves a number of isolates with a high antagonistic activity in relation to pathogens of plant diseases (Table 1).

Among the isolates, as a potential biological control agent UzNU-18 isolate was of special interest due to its broad spectrum of antagonistic action and the highest inhibition activity in growth studies on fungi and bacteria.

According to morphological-cultural and physiological-biochemical properties (Table 2), and based on 16S rRNA partial sequence similarity (99\% identical to previously known Bacillus subtilis strain BGSC, NR_104873.1), the UzNU-18 isolate was identified as Bacillus subtilis (GenBank accession number: MH312004) and deposited into Collection of Industrially Important Microorganisms of the Institute of Microbiology of the Academy of Sciences of Uzbekistan under the number SKB-256. 


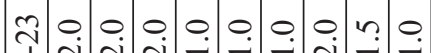

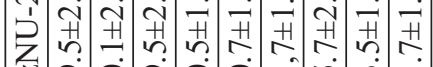

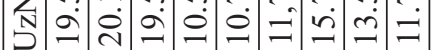

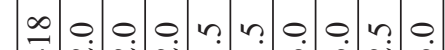

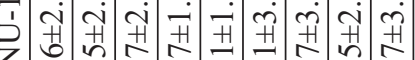

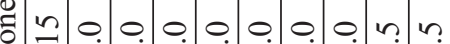

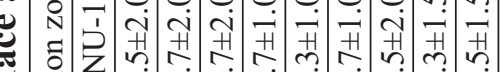
党:

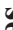

o

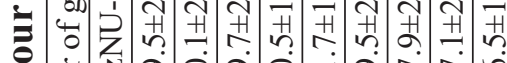
है 政

\section{.}

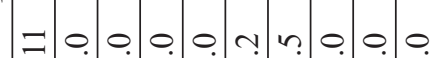

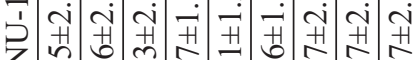
N

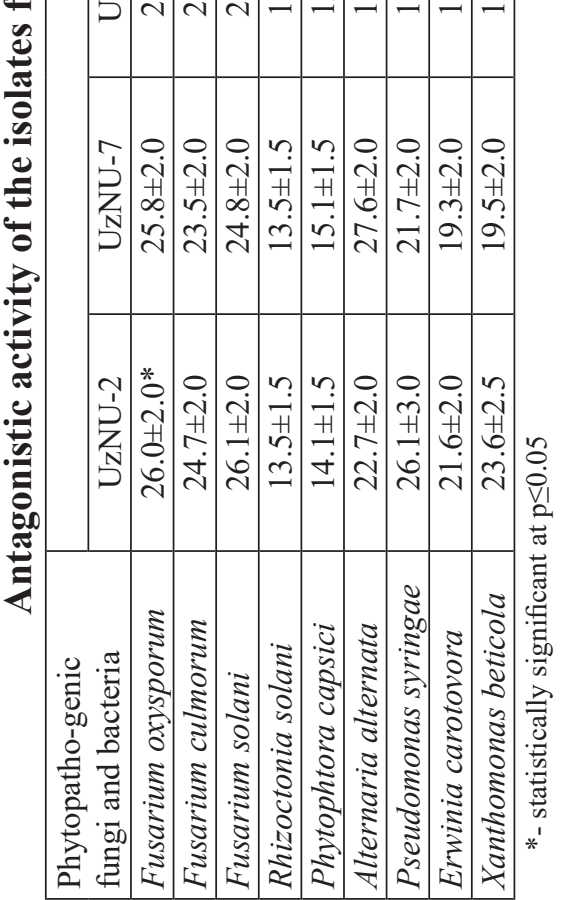


Characteristics of the isolate Bacillus subtilis UzNU-18

\begin{tabular}{|c|c|c|c|}
\hline \multicolumn{2}{|c|}{ Characteristics and properties } & \multicolumn{2}{|c|}{ Characteristics and properties } \\
\hline Size, $\mu \mathrm{m}$ & $0.7 \times 2.4$ & Fermentation of: & \\
\hline Motility & + & Glucose & + \\
\hline Spore formation & + & Fructose & + \\
\hline Gram staining & + & Lactose & + \\
\hline Aerobic growth & + & Maltose & + \\
\hline Anaerobic growth & - & Sucrose & + \\
\hline Growth at $7 \% \mathrm{NaCl}$ & + & Xylose & + \\
\hline Hydrolysis of: & & Cellobiose & + \\
\hline Gelatine & + & Arabinose & + \\
\hline Starch & + & Sorbitol & - \\
\hline Casein & + & Starch & + \\
\hline Nitrate reduction & + & Glycerol & + \\
\hline Catalase & + & Dulcitol & - \\
\hline Oxidase & - & Galactose & - \\
\hline Urease & - & Inositol & + \\
\hline Voges-Proskauer & + & Inulin & + \\
\hline Utilization of: & & Mannitol & + \\
\hline Citrate & + & Mannose & + \\
\hline Propionate & - & Raffinose & + \\
\hline Lecithinase & - & Rhamnose & - \\
\hline Crystal formation & - & Ribose & + \\
\hline Indole & - & Salicin & + \\
\hline $\mathrm{H}_{2} \mathrm{~S}$ production & - & Trehalose & + \\
\hline D-mannose & + & & \\
\hline Salicin & + & & \\
\hline Starch & + & & \\
\hline D-xylose & + & & \\
\hline
\end{tabular}

Note: «+» - presence of characteristic or property, «-» - absence of characteristic or property

The following nutrient media composition was selected for fast growth and synthesis of antimicrobial metabolites by Bacillus subtilis UzNU-18 (g/L): corn extract 5.0; molasses - 30.0; $\mathrm{KH}_{2} \mathrm{PO}_{4}-2.0 ; \mathrm{K}_{2} \mathrm{HPO}_{4}-1.0 ; \mathrm{MgSO}_{4} \times 7 \mathrm{H}_{2} \mathrm{O}-$ $0.05 ;\left(\mathrm{NH}_{4}\right) \mathrm{MoO}_{4} \times 5 \mathrm{H}_{2} \mathrm{O}-0.01 ;\left(\mathrm{NH}_{4}\right) \mathrm{NO}_{3}-1.5$; extract from the cottonseed meal - 20.0; tap water up to $1 \mathrm{~L}$. Optimization of cultivation conditions of the strain was carried out and resulted in the maximum antagonistic activity at $34-36^{\circ} \mathrm{C}$. This temperature was also found to be the most favorable for the growth of Bacillus subtilis UzNU-18 (Table 3).

At optimized cultivation conditions, the yield of biomass was $4.2-4.5 \mathrm{~g} / \mathrm{L}$ with almost complete utilization of saccharified substances (up to 95\%) in the nutrient media. When the temperature was lowered to $20^{\circ} \mathrm{C}$, the growth rate of culture slowed down.

It should be noted that Bacillus subtilis UzNU-18 grows well in $\mathrm{pH}$ range from 5.0 to 8.5 . The most favourable conditions for the exhibition of antagonistic activity were achieved at $\mathrm{pH}$ 6.0-8.5 with an optimum $\mathrm{pH} 7.0$ (Table 3 ). Beyond these limits of $\mathrm{pH}$, the antimicrobial activity of the culture was markedly reduced. 
Influence of temperature and pH on antagonistic activity of Bacillus subtilis UzNU-18

\begin{tabular}{|c|c|c|c|}
\hline \multirow{2}{*}{$\begin{array}{l}\text { Cultivation } \\
\text { parameters }\end{array}$} & \multirow{2}{*}{ Duration of cultivation, $\mathrm{h}$} & \multicolumn{2}{|c|}{ Diameter of growth inhibition zone, $\mathrm{mm}$} \\
\hline & & Fusarium oxysporum & Fusarium solani \\
\hline Temperature, ${ }^{\circ} \mathrm{C}$ & 24 & $6.5 \pm 0.2 *$ & $6.3 \pm 0.2 *$ \\
\hline \multirow{2}{*}{$20-26$} & 48 & $7.2 \pm 0.3$ & $7.8 \pm 0.3$ \\
\hline & 72 & $8.3 \pm 0.3$ & $8.7 \pm 0.3$ \\
\hline \multirow{3}{*}{$28-32$} & 24 & $7.6 \pm 0.3$ & $7.8 \pm 0.3$ \\
\hline & 48 & $8.3 \pm 0.3$ & $8.6 \pm 0.3$ \\
\hline & 72 & $8.7 \pm 0.3$ & $9.1 \pm 0.3$ \\
\hline \multirow{3}{*}{$34-36$} & 24 & $28.3 \pm 0.3$ & $27.7 \pm 0.3$ \\
\hline & 48 & $35.1 \pm 0.4$ & $34.4 \pm 0.4$ \\
\hline & 72 & $33.2 \pm 0.4$ & $32.3 \pm 0.4$ \\
\hline \multirow{3}{*}{$37-39$} & 24 & $23.2 \pm 0.3$ & $24.1 \pm 0.3$ \\
\hline & 48 & $25.1 \pm 0.3$ & $26.1 \pm 0.3$ \\
\hline & 72 & $24.7 \pm 0.3$ & $25.3 \pm 0.3$ \\
\hline \multirow{3}{*}{$40-42$} & 24 & $12.5 \pm 0.2$ & $11.8 \pm 0.2$ \\
\hline & 48 & $11.7 \pm 0.2$ & $11.7 \pm 0.2$ \\
\hline & 72 & $10.7 \pm 0.2$ & $10.5 \pm 0.2$ \\
\hline \multicolumn{4}{|l|}{ pH value } \\
\hline 4.5 & 48 & $20.6 \pm 0.2$ & $19.7 \pm 0.2$ \\
\hline 5.0 & 48 & $21.5 \pm 0.2$ & $20.1 \pm 0.2$ \\
\hline 5.5 & 48 & $22.1 \pm 0.2$ & $22.5 \pm 0.2$ \\
\hline 6.0 & 48 & $27.6 \pm 0.3$ & $26.1 \pm 0.3$ \\
\hline 6.5 & 48 & $32.5 \pm 0.4$ & $31.8 \pm 0.4$ \\
\hline 7.0 & 48 & $35.3 \pm 0.4$ & $34.5 \pm 0.4$ \\
\hline 7.5 & 48 & $32.1 \pm 0.4$ & $31.7 \pm 0.4$ \\
\hline 8.0 & 48 & $31.0 \pm 0.4$ & $28.6 \pm 0.3$ \\
\hline 8.5 & 48 & $27.6 \pm 0.3$ & $25.9 \pm 0.3$ \\
\hline 9.0 & 48 & $23.1 \pm 0.3$ & $21.7 \pm 0.3$ \\
\hline
\end{tabular}

*- statistically significant at $\mathrm{p} \leq 0.05$. Cultivated on a shaker at $180 \mathrm{rpm}$.

Results showed that the highest growth rate of the strain $(\mu \max =0.30$ $0.32 \mathrm{~h}$ ) and the accumulation of biomass (4.5-4.8 g/L) can be achieved by cultivation in $250 \mathrm{ml}$ Erlenmeyer flasks with $100 \mathrm{ml}$ of nutrient media and rotation speed of $180 \mathrm{rpm}$. Decreasing the rotation speed to less than $150 \mathrm{rpm}$, as well as increasing it to more than $220 \mathrm{rpm}$ leads to lower $\mu$ max and biomass accumulation.

The dynamics of Bacillus subtilis UzNU-18 growth under optimized conditions obeys the general rules of culture growth during periodic cultivation, i.e. before the culture active growth phase an adaptation period takes 5-6 hours. The exponential growth phase is short $-4-5$ hours. After the period of slow growth, which lasts 18-24 hours, a phase of steady growth takes place and lasts for about $20 \mathrm{~h}$. The maximum accumulation of biomass $(4.8 \mathrm{~g} / \mathrm{L})$ was observed in 30-32 hours after cultivation started (Fig. 1 A). By this time about $70 \%$ and in 50-52 hours $-95 \%$ of nutrients had been consumed (Fig. $1 \mathrm{~B}$ ). 

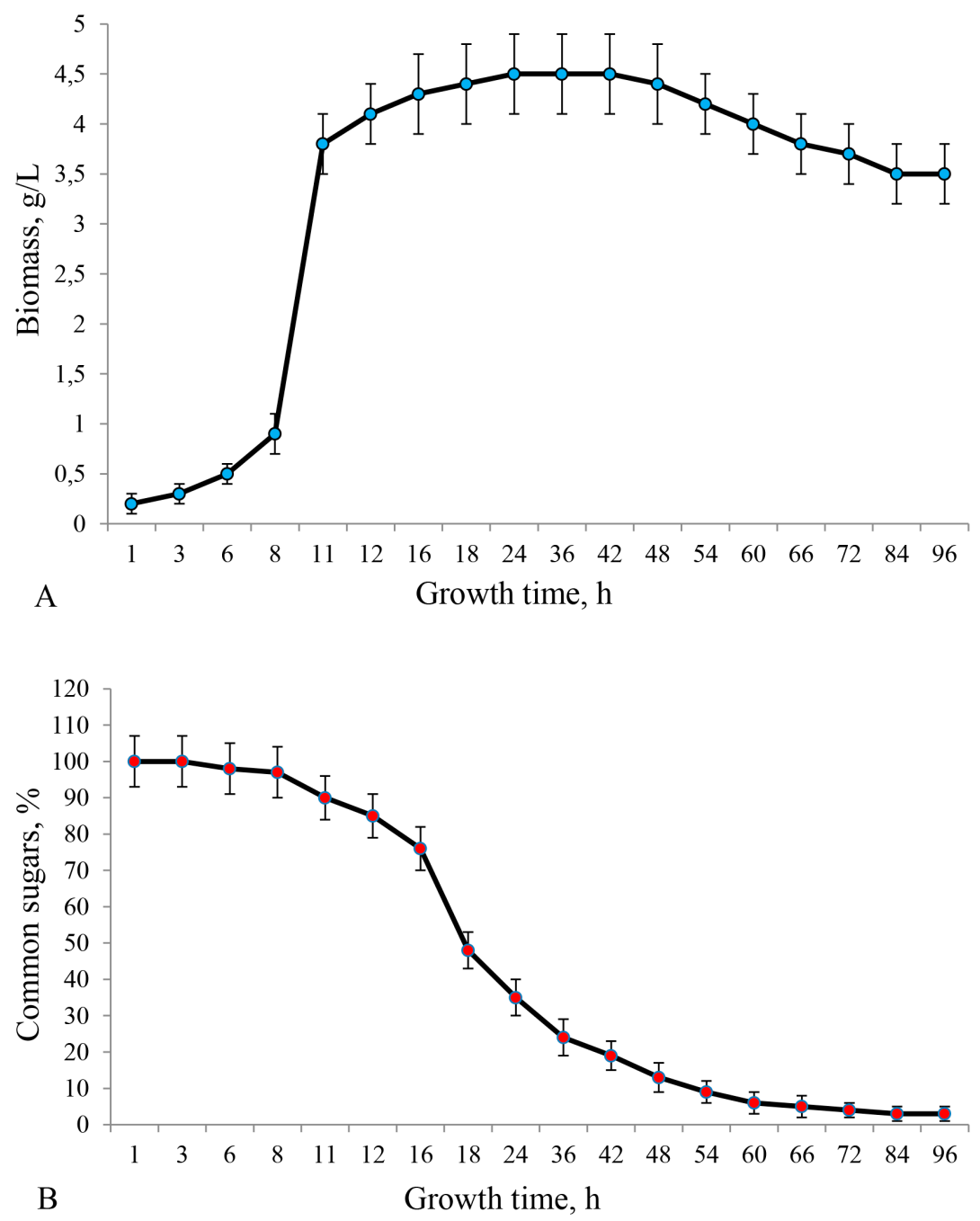

Fig. 1. Dynamics of Bacillus subtilis UzNU-18 growth on optimized medium (shaking speed $180 \mathrm{rpm}$ ); A-biomass, g/L; B-reducing substances, \%. All results are statistically significant at $\mathbf{p} \leq \mathbf{0 . 0 5}$.

The maximum antagonistic activity of Bacillus subtilis UzNU-18 (diameter of Fusarium oxysporum growth inhibition zone was $35.3 \pm 0.4 \mathrm{~mm}$, and Pseudomonas syringae lysis zone was $34.5 \pm 0.4 \mathrm{~mm}$ ) was noticed at the end of stationary phase (48-56 h) of culture growth (Fig. 2).

Thus, it was experimentally established that optimal conditions for growth and accumulation of antifungal metabolites by Bacillus subtilis UzNU-18 in the optimized media consisting of cottonseed meal extract, molasses, microand macro elements, are achieved at $34-36^{\circ} \mathrm{C}, \mathrm{pH} 7.0$ and shaker speed of $180 \mathrm{rpm}$.

Bacillus subtilis UzNU-18 behaves differently with respect to the tested microorganisms. For example, growth of phytopathogenic bacteria Pseudomonas, Ervinia, Xanthomonas and fungi Fusarium and Alternaria, was inhibited more strongly based on the formation of inhibition zones than in the case of fungi Phytophthora and Rhizoctonia. 


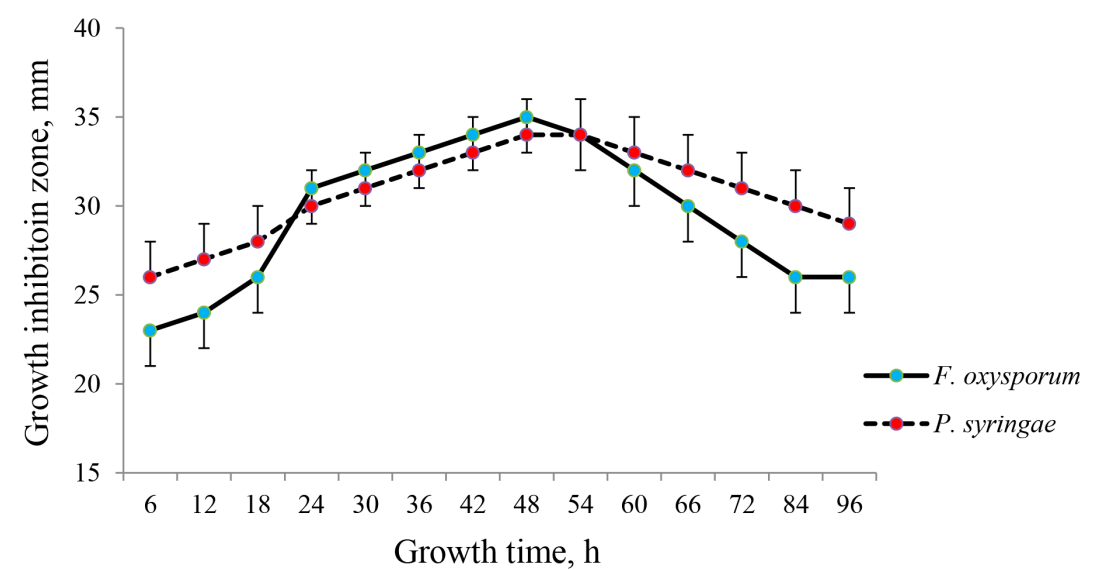

Fig. 2. Dynamics of antagonistic activity of Bacillus subtilis UzNU-18 against Fusarium oxysporum and Pseudomonas syringae on optimized medium (shaking speed $180 \mathrm{rpm}$ ). All results are statistically significant at $\mathbf{p} \leq \mathbf{0 . 0 5}$.

The next stage of our research was aimed at isolation and study of Bacillus subtilis UzNU-18 metabolites, exhibiting antimicrobial activity. Antagonistic activity of the intact cells in liquid culture, as well as bacterial homogenate obtained by disintegration for 3 minutes were evaluated. It was determined that the culture liquid of intact cells contained metabolites with antibacterial action. To isolate the metabolites from culture liquid, various organic solvents were used and methanol was found to have the highest extractive capacity.

Table 4

Effect of Bacillus subtilis UzNU-18 on a wheat seedlings growth

\begin{tabular}{|c|c|c|c|c|c|}
\hline \multirow{3}{*}{ Experiments variants } & \multirow{3}{*}{$\begin{array}{c}\text { Bacillus } \\
\text { subtilis } \\
\text { UzNU-18, } \\
\text { CFU } / \mathrm{ml}\end{array}$} & \multicolumn{4}{|c|}{ Seedlings weight (per 1 plant) } \\
\hline & & \multirow[b]{2}{*}{$\mathrm{mg}$} & \multicolumn{3}{|c|}{$\%$ to control } \\
\hline & & & $\mathrm{K}_{1}$ (soil) & $\begin{array}{c}\mathrm{K}_{2}(\text { soil }+ \\
\text { F.oxysporum })\end{array}$ & $\begin{array}{c}\mathrm{K}_{3} \text { (soil+ } \\
\text { P.syringae) }\end{array}$ \\
\hline $\mathrm{K}_{1}$ (soil) & - & $15.6 \pm 0.5^{*}$ & 100 & - & - \\
\hline $\mathrm{K}_{2}($ soil + F.oxysporum $)$ & - & $14.1 \pm 0.5$ & 90.4 & 100 & - \\
\hline $\mathrm{K}_{3}$ (soil + P.syringae $)$ & - & $14.2 \pm 0.5$ & 91.0 & - & 100 \\
\hline Soil+B.subtilis UzNU-18 & $10^{6}$ & $16.1 \pm 0.6$ & 103.2 & - & - \\
\hline Soil+B.subtilis UzNU-18 & $10^{7}$ & $17.3 \pm 0.6$ & 110.9 & - & - \\
\hline Soil+B.subtilis UzNU-18 & $10^{8}$ & $18.1 \pm 0.6$ & 116.0 & - & - \\
\hline $\begin{array}{l}\text { Soil+B.subtilis UzNU-18+ } \\
\text { F.oxysporum }\end{array}$ & $10^{6}$ & $16.9 \pm 0.6$ & 108.3 & 119.8 & - \\
\hline $\begin{array}{l}\text { Soil+B.subtilis UzNU-18+ } \\
\text { F.oxysporum } \\
\end{array}$ & $10^{7}$ & $18.2 \pm 0.6$ & 117.0 & 129.0 & - \\
\hline $\begin{array}{l}\text { Soil+B.subtilis UzNU-18+ } \\
\text { F.oxysporum }\end{array}$ & $10^{8}$ & $17.9 \pm 0.6$ & 114.7 & 126.9 & - \\
\hline $\begin{array}{l}\text { Soil+B.subtilis UzNU-18+ } \\
\text { P.syringae }\end{array}$ & $10^{6}$ & $15.0 \pm 0.6$ & 96.1 & - & 93.2 \\
\hline $\begin{array}{l}\text { Soil+B.subtilis UzNU-18+ } \\
\text { P.syringae }\end{array}$ & $10^{7}$ & $15.1 \pm 0.6$ & 96.8 & - & 93.8 \\
\hline $\begin{array}{l}\text { Soil+B.subtilis UzNU-18+ } \\
\text { P.syringae }\end{array}$ & $10^{8}$ & $15.9 \pm 0.6$ & 101.9 & - & 98.8 \\
\hline
\end{tabular}

*- statistically significant at $\mathrm{p} \leq 0.05$ 
The extractive capacity of organic solvents, including methanol, depended on $\mathrm{pH}$ of the extracted culture liquid. It was established that antagonistic metabolites of Bacillus subtilis UzNU-18 can be easily isolated from supernatant acidified to $\mathrm{pH}$ 3.5.

Six spots were observed from methanol extract fractions developed on the silufol plates in the p-butanol -acetic acid - water system (4:1:1, v/v/v). Using bioautography showed that fraction with Rf- 0.45 with maximum absorption at $265-275 \mathrm{~nm}$ showed antimicrobial activity. According to the data of a liquid chromatography mass spectrometry, this substance was identified as 2.4-dimethyl-3-pentanone.

At the final stage of the study we conducted model experiments. We used culture media with various titers of Bacillus subtilis UzNU-18 to evaluate its plant-protective effect of on wheat seedlings (Table 4) and observed a decrease in the number of populations of phytopathogenic fungi and bacteria at all tested concentrations. Reduction of the infection contributed to active growth of wheat seedlings.

Discussion. The expediency of studying epiphytic microorganisms, first of all, is related to their effectiveness. Many epiphytic microorganisms in the phyllosphere of plants form stable communities and protect their host from penetration of pathogens $[18,19]$. We isolated and identified a strain Bacillus subtilis UzNU-18, possessing high antagonistic activity against phytopathogenic fungi and bacteria. High antagonistic activity of the strain was conditioned by synthesis of 2.4-dimethyl-3-pentanone. This compound belongs to a group of aliphatic ketones known for their antimicrobial activity. For example, similar substance was isolated from Bacillus pumilus BIM B-263 culture liquid supernatant [20]. A similar substance - 1.3-dihydroxy-2propanone and its derivatives are synthesized by bacteria of genera Acetobacter, Aerobacter, Gluconobacter and Streptomyces. Due to their antimicrobial properties they are used in medicine, as well as in agriculture as repellents and fungicides [21]. High biological activity of the studied strain was confirmed in a laboratory model experiment with wheat seedlings.

Acknowledgements: we are grateful to Mr. Jakhongir Alimov from the National University of Uzbekistan for his help in conducting some experiments.

Funding: The work was supported by the local grant MV-QH-AQH-2018-91 "Environmental aspects of microbial agents use in different conditions of the agrocenosis of Jizzakh and Syrdarya regions" from the Ministry of Innovational Development of the Republic of Uzbekistan. 


\title{
ЕПIФITHА БАКТЕРІЯ ВACILLUS SUBTILIS UZNU-18 \\ З ЕРУСАЛИМСЬКОГО АРТИШОКУ \\ (HELIANTHUS TUBEROSUS L.) - АКТИВНИЙ \\ БІОКОНТРОЛЬНИЙ АГЕНТ ФІТОПАТОГЕННИХ \\ МІКРООРГАНІЗМІВ
}

\author{
К. Давранов, В.В. Шуригін ${ }^{1}$, А. Маммадіев, Х.К. Рузімова ${ }^{1}$ \\ ${ }^{1}$ Національний університет Узбекистану, вул. Університетська, 4, \\ Ташкент, 100174, Узбекистан \\ ${ }^{2}$ Термезській Державний університет, вул. Ходжаєва, 43, \\ Термез, Сурхандарья, 732011, Узбекистан
}

\section{Резюме}

3 зеленого листя Єрусалимського артишоку, також відомого як топінамбур (Helianthus tuberosus L.), нами було виділено новий штам бактерій, що належить до роду Bacillus. Метою даної роботи було вивчення фізіолого-біохімічних властивостей епіфітного штаму Bacillus subtilis UzNU-18, його антагоністичної активності і умов формування антимікробних метаболітів, синтезованих цим штамом. Методи. Використовували стандартні мікробіологічні, молекулярно-біологічні, біохімічні, хроматографічні та статистичні методи. Результати. Епіфітні мікроорганізми відіграють важливу роль у захисті своїх господарів від інфікування патогенами. Ізолят UzNU-18 був виділений з поверхні зеленого листя Єрусалимського артишоку, також відомого як топінамбур (Helianthus tuberosus L). В ході дослідження цей ізолят обраний як кращий інгібітор росту тестованих фітопатогенних грибів (Fusarium oxysporum, Fusarium culmorum, Fusarium solani, Rhizoctonia solani, Phytophtora capsici, Alteranria alternata) і бактерій (Pseudomonas syringae, Erwinia carotovora, Xanthomonas beticola). Аналіз 16S рРНК показав, що ізолят (GenBank accession \# MH312004) є Bacillus subtilis. Хромато-мас-спектрометричний аналіз показав, що Bacillus subtilis UzNU-18 продукує антагоністичну речовину 2,4-діметілпентаноном-3. Висновки. Інокуляція грунту культуральною рідиною Bacillus subtilis UzNU-18 знижувала інфекцію в грунті і сприяла кращому росту проростків пшениці.

Ключові слова: епіфітний, Bacillus subtilis, фітопатогенні гриби, топінамбур, антагоністична активність. 


\title{
ЭПИФИТНАЯ БАКТЕРИЯ ВАCILLUS SUBTILIS UZNU-18 ИЗ ИЕРУСАЛИМСКОГО АРТИШОКА \\ (HELIANTHUS TUBEROSUS L.) - АКТИВНЫЙ БИОКОН- ТРОЛЬНЫЙ АГЕНТ ФИТОПАТОГЕННЫХ МИКРООРГАНИЗМОВ
}

\author{
К. Давранов ${ }^{I}$ В.В. Шурыгин ${ }^{1}$, А. Маммадиев ${ }^{2}$ Х.К. Рузимова \\ ${ }^{1}$ Национальный университет Узбекистана, ул. Университетская, 4, \\ Ташкент, 100174, Узбекистан \\ ${ }^{2}$ Термезский Государственный университет, ул. Ходжаева, 43, \\ Термез, Сурхандарья, 732011, Узбекистан

\section{Резюме}

Из зелёных листьев Иерусалимского артишока, также известного как топинамбур (Helianthus tuberosus L.), нами был выделен новый штамм бактерий, принадлежащий к роду Bacillus. Целью данной работы было изучение физиолого-биохимических свойств эпифитного штамма Bacillus subtilis UzNU-18, его антагонистической активности и условий образования антимикробных метаболитов, синтезируемых этим штаммом. Методы. Использовали стандартные микробиологические, молекулярно-биологические, биохимические, хроматографические и статистические методы. Результаты. Эпифитные микроорганизмы играют важную роль в защите своих хозяев от инфицирования патогенами. Изолят UzNU-18 был выделен с поверхности зелёных листьев Иерусалимского артишока, также известного как топинамбур (Helianthus tuberosus L). В ходе исследования этот изолят выбран как лучший ингибитор роста тестируемых фитопатогенных грибов (Fusarium oxysporum, Fusarium culmorum, Fusarium solani, Rhizoctonia solani, Phytophtora capsici, Alteranria alternata) и бактерий (Pseudomonas syringae, Erwinia carotovora, Xanthomonas beticola). Анализ 16S pРНК показал, что изолят (GenBank accession \# MH312004) является Bacillus subtilis. Хромато-масс-спектрометрический анализ показал, что Bacillus subtilis UzNU-18 продуцирует антагонистическое вещество - 2,4-диметилпентаноном-3. Выводы. Инокуляция почвы культуральной жидкостью Bacillus subtilis UzNU-18 снижала содержание инфекции в почве и способствовала лучшему росту проростков пшеницы.

Ключевые слова: эпифитный, Bacillus subtilis, фитопатогенные грибы, топинамбур, антагонистическая активность.

1. Lambers H, Mougel C, Jaillard B, Hinsinger Ph. Plant-microbe-soil interactions in the rhizosphere: an evolutionary perspective. Plant and Soil. 2009; 321(1-2):83-115.

2. Vimal SR, Singh JS, Arora NK, Singh S. Soil-plant-microbe interactions in stressed agriculture management: A review. Pedosphere. 2017; 27(2):177-192.

3. Food and Agriculture Organization of the United Nations (FAO). The state of food and agriculture. Rome; 2013. Available from: http:/www.fao.org/docrep/018/i3300e/ i3300e.pdf

4. Khujamshukurov NA. The development of insecticide biopreparation on the basis of bacteria Bacillus thuringiensis and its introduction into practice. Tashkent; 2017. Uzbek.

5. Kumar A, Prakash A, Johri BN. Bacillus as PGPR in crop ecosystem. In: Maheshwari DK, editor. Bacteria in Agrobiology: Crop Ecosystems. Berlin Heidelberg: SpringerVerlag; 2011. p. 37-59. 
6. Collins D, Stevens C, Khan V, Nightengale S. Commercial biopreparations of Bacillus subtilis. Phytopathology. 1994; 84(10):1114-1119.

7. Bacillus subtilis strain QST 713. EU Pesticides database. Available from: http://ec.europa. $\mathrm{eu} /$ food/plant/pesticides/eu-pesticides-database/public/?event=activesubstance.detail\& language $=\mathrm{DE} \&$ selectedID $=986$

8. Tetreau G, Patil CD, Chandor-Proust A, Salunke BK, Patil SV, Despres L. Production of the bioinsecticide Bacillus thuringiensis subsp. israelensis with deltamethrin increases toxicity towards mosquito larvae. Letters Appl Microbiol. 2013; 57:151-156.

9. Sarma SJ, Brar SK. Industrial Production of Bacillus Thuringiensis Based Bio-Insecticide: Which Way Forward? J Biofert Biopest. 2015; 6:1.

10. Bacillus pumilus strain QST 2808 (006485) Fact Sheet. Available from: https://www3. epa.gov/pesticides/chem_search/reg_actions/registration/fs_PC-006485_14-Oct-04.pdf

11. Segi Y. [Methods of soil microbiology]. Moscow: Kolos; 1983. Russian.

12. De Vos P, Garrity GM, Jones D, Krieg NR, Ludwig W, Rainey FA, Schleifer K-H, William B. Bergey's manual of systematic bacteriology. 2nd ed. Whitman: Springer; 2009.

13. Sanger F, Coulson AR. A rapid method for determining sequences in DNA by primed synthesis with DNA polymerase. J Mol Biol. 1975; 94(3):441-446.

14. Reddy CA. Methods for general and molecular microbiology. 3rd ed. Washington: ASM press; 2007.

15. Netrusov AI, Egorova AI, Zaharchuk LM. [Practicum on microbiology]. Moscow: Academiya; 2005. Russian.

16. Peterburgskiy A.V. [Practicum on agronomical chemistry]. Leningrad: Kolos; 1968. Russian.

17. Kirchner Yu. [Thin layer chromatography]. V 1. Moscow: Mir; 1981. Russian.

18. Yuen GY, Godoy G, Steadman JR, Kerr ED, Craig ML. Epiphytic colonization of dry edible bean by bacteria antagonistic to Sclerotinia sclerotiorum and potential for biological control of white mold disease. Biol Control. 1991; 1(4):293-301.

19. Lanna RF, Romeiro RS, Alves E. Bacterial spot and early blight biocontrol by epiphytic bacteria in tomato plants. Pesquisa Agropecuaria Brasileira. 2010; 45(12):1381-1387.

20. Kolomiec EI, Sverchkova NV, Romanovskaya TV, Bezzubov VI. [Bacterial strain Bacillus pumilus BIM B-263 possessing antagonistic activity to microorganisms causative agents of plants and animals diseases]. Republic of Belarus Patent BY 9685. 2007. Russian.

21. Dombrovskaya VA, Overchenko MB. [Multipurpose use of dioxoacetone in the national economy]. Biotechnology. 1988; 4(5):643-647. Russian.

Отримано 4.02. 2019 